\title{
Barns upplevelser av instabil samhällsvård
}

\author{
VIKTORIA SKOOG
}

\begin{abstract}
Forskning har visat på otillräcklig stabilitet för barn i samhällsvård. Denna artikel undersöker hur barnen, som står i centrum för samhällsvården, upplever instabilitet och hur de förstår orsakerna till att vården är instabil.
\end{abstract}

\section{Introduktion}

I Sverige var 19600 barn i åldern 0-17 år placerade utanför hemmet någon gång under 2011 (Socialstyrelsen 2012). Ansvaret för barn i samhällsvård ligger hos den kommunala socialtjänsten och de placeras i familjehem eller på institutioner. Barn som befinner sig i samhällsvård kommer i hög grad från strukturellt utsatta familjer med fattigdom och ensamstående föräldraskap. Många har föräldrar med problematik t.ex. i form av missbruk och/eller psykisk ohälsa (Khoo m.fl. 2012). En grundtanke med vården är att barnens möjligheter att utvecklas väl ska öka. Samhällsvården som ska erbjuda barn en solidare tillvaro än vad

Viktoria Skoog, socionom och doktorand, FoUVästernorrland och Umeå universitet. barnen hade i hemmiljön har dock visat sig vara instabil och kantas av nya uppbrott för barnen (Egelund 2006). Instabilitet, dvs. planerade byten av vårdmiljöer eller oplanerade sammanbrott av vården, är vanligt i såväl Nordamerika, Europa som Australien (Unrau 2007). Sammanbrott definieras i denna studie, enligt Vinnerljungs m.fl. (2001) definition, dvs. att vården avbryts plötsligt och oplanerat. Det kan ske på initiativ av barnen, vårdgivarna, socialtjänsten eller de biologiska föräldrarna. Planerade byten av vårdmiljöer definieras som att barn utifrån en planering från socialtjänsten byter vårdgivare inom den sociala barnavården. Detta kan bero på att barnen initialt jourplaceras och sedan flyttas till en mer långsiktig lösning eller att vården "trappas ned" utifrån att barn flyttas från en strukturerad till en mer öppen vårdform (Ward 2009). Det är svårt att veta hur rele- 
vanta dessa definitioner är ur barnens perspektiv. Rostill-Brookes m.fl. (2011) visar t.ex. att barn benämner sammanbrott med helt andra ord som "moving", "leaving" och "not being wanted". Det är dessutom långt ifrån säkert att barnen och socialtjänsten har samma uppfattning om skälet till att en placering avslutas.

Kunskapen om hur barn upplever instabilitet är begränsad (Egelund 2006; RostillBrookes m.fl. 2011) och handlar nästan uteslutande om tonåringars upplevelser (barn i åldern 13-17 år). Den forskning som dominerar området idag fokuserar på omfattningen av och riskfaktorer för instabilitet. Riskfaktorerna, det vill säga faktorer som i studier har visat sig öka risken för instabilitet, gäller i stor utsträckning egenskaper hos barn. Detta kan bero på att studier vanligtvis baseras på socialtjänstens barnavårdsakter (Egelund m.fl. 2010; Unrau 2007). Akterna innehåller främst information om barnen och deras föräldrar, vilket gör riskfaktorer kopplade till andra aktörer svåra att upptäcka. Att studera instabilitet genom kvantitativa metoder är oundgängligt för att få en uppfattning av just förekomst och riskfaktorer, men har också sina begränsningar. Som enda angreppssätt riskerar det att, likt Egelund m.fl. (2010) beskriver, framställa instabilitet som en enskild händelse istället för något som sker i en process. Riskfaktorer reduceras då till egenskaper hos individer istället för att ses som något skapat i samspel mellan flera aktörer.

Syftet med denna artikel är att undersöka barns upplevelser av instabil samhällsvård samt hur de förstår orsakerna till att vården är instabil.

\section{Områdesöversikt}

Det finns en mängd studier om instabilitet för barn i samhällsvård men dessa är svåra att jämföra med varandra. Skälen till det är bl.a. att forskningen berör barnavårdssystem som skiljer sig åt mellan olika länder, att begrepp sällan definieras trots att terminologin på området är omfattande samt att forskningsdesignen varierar t.ex. gällande urval och uppföljningstid (Unrau 2007; Vinnerljung m.fl. 2001). Denna områdesöversikt diskuterar instabilitet som mått på samhällsvårdens kvalité samt redogör för de mest samstämmiga resultaten i tidigare forskning om frekvenser och riskfaktorer för instabilitet.

Instabilitet har betydelse för samhällsvårdens kvalité även om det inte går att använda som enda mått. Barn som varit med om instabilitet ger exempel på hur de upplevt situationen stressfylld, lämnat sin sociala tillvaro (bytt bostadsmiljö, skola och vänner), inte haft tillgång till information om vad som händer, känt sig känslomässigt avtrubbade samt upplevt en känsla av att allt kan förändras i tillvaron (Hyde \& Kammerer 2009; Rostill-Brookes m.fl. 2011; Ward 2009). Studier visar också att vuxna som erfarit instabilitet, när de befann sig i samhällsvård som barn, upplever att det påverkat dem negativt i vuxenlivet. De berättar att tilliten till andra människor och tilltron till möjligheten att skapa hållbara relationer har skadats samt att instabiliteten skapat känslor av förlust av materiella ting, relationer och kontroll över livet (Coy 2009; Unrau m.fl. 2008). Samband har också påvisats mellan instabilitet och ökade beteende- och emotionella 
problem hos barn (Newton m.fl. 2000) samt mellan erfarenhet av sammanbrott $i$ tonåren och sämre långsiktiga prognoser $\mathrm{i}$ vuxenlivet (Vinnerljung \& Sallnäs 2008).

Resultat angående frekvenser för instabilitet varierar, t.ex. beroende på vilken typ av instabilitet som studeras och vilken population som undersöks. I forskningsöversikter som studerat sammanbrott varierar frekvenser mellan 20-40 \% (Egelund 2006; Oosterman m.fl. 2007). Forskning visar att ju äldre barn är när de placeras desto större risk för sammanbrott (Oosterman m.fl. 2007; Vinnerljung m.fl. 2001). Det betyder inte att yngre barn (som inte nått tonåren d.v.s. barn under 13 år) har stabil vård. Den vanligaste orsaken till instabilitet för yngre barn är planerade byten av vårdmiljöer (Christiansen m.fl. 2010; Ward 2009). Den enda svenska studie som omfattar både sammanbrott och planerade byten av vårdmiljöer visar att förskolebarn (0-6 år) och tonåringar (13-17 år) nästan i lika hög utsträckning avslutade placeringar på grund av instabilitet. För förskolebarnen berodde det på planerade byten av vårdmiljöer och för tonåringar på sammanbrott (Skoog m.fl. 2012). Sammanbrott sker ofta i och med att barn rymmer eller vägrar stanna kvar $i$ vården (Skoog m.fl. 2012; Vinnerljung m.fl. 2001) vilket gör att yngre barn av naturliga skäl inte har samma möjligheter att initiera sammanbrott.

När det gäller riskfaktorer för instabilitet finns relativt samstämmiga forskningsresultat som visar att större risk för instabilitet föreligger för barn som varit med om tidigare placeringar eller sammanbrott (Oosterman m.fl. 2007; Strijker m.fl. 2008;
Vinnerljung m.fl. 2001) samt för barn med beteendeproblem (Newton m.fl. 2000; Oosterman m.fl. 2007; Strijker m.fl. 2008; Vinnerljung m.fl. 2001; Ward 2009). Även om forskning ofta anger barns beteendeproblem som en riskfaktor är frågan om vad som är "hönan och ägget" obesvarad i de flesta studier. Barn som varit med om instabilitet beskriver utåtagerande beteende som en reaktion på vad de utsätts för och något som uppstår i relation till andra aktörer (Hyde \& Kammerer 2009).

Det finns studier, främst gällande sammanbrott, som undersökt riskfaktorer kopplade till vårdmiljön, socialtjänsten och biologiska föräldrar. För vårdmiljön har typ av placering i vissa studier visat sig ha betydelse för instabilitet (Oosterman m.fl. 2007; Vinnerljung m.fl. 2001) men det finns också resultat som inte visar på några signifikanta skillnader mellan instabilitet och placeringsform (Egelund m.fl. 2010). En minskad risk för instabilitet $i$ släktingplaceringar redovisas i ett flertal studier och litteraturöversikter (Chamberlain m.fl. 2006; Egelund 2006; Vinnerljung m.fl. 2001) men det finns även studier som visat att skillnaden är marginell (Oosterman m.fl. 2007) eller att risken ökar (Ward 2009). Att barn placeras i familjehem med yngre eller jämnåriga biologiska barn till familjehemsföräldrar, har visat sig vara en riskfaktor för sammanbrott (Oostermans m.fl. 2007; Vinnerljung m.fl. 2001). När det gäller socialsekreterares påverkan ökar risken för sammanbrott om barn byter socialsekreterare och om finansiella restriktioner gör det svårt att finna en optimal vårdmiljö (Egelund m.fl. 2010). För riskfaktorer kopplade till föräldrarnas situation finns få 
samstämmiga resultat (Egelund 2006; Vinnerljung m.fl. 2001).

\section{Metod}

Denna studie använder tolkande fenomenologi som metod vilket innebär att den studerar hur människor ger mening till sina upplevelser av betydelsefulla händelser (Smith m.fl. 2009). Tolkande fenomenologi är därmed ett lämpligt angreppssätt för att undersöka barns upplevelser av instabil samhällsvård. Metoden går från att beskriva upplevelser till att analysera och tolka dessa i sin kontext (Larkin m.fl. 2006). Studien eftersträvar därmed inte att empiriskt undersöka vad som faktiskt hänt utan syftar till att beskriva och analysera hur barnen upplever och förstår instabilitet. Studien är godkänd av regionala etikprövningsnämnden i Umeå, dnr 2010-300-31Ö.

\section{Respondenter}

Studien baseras på intervjuer med 12 barn och unga vuxna i åldern 8-18 år. Sammanbrott användes som utgångspunkt för urval men även planerade byten av vårdmiljöer studerades. Studien undersöker barns upplevelser och därmed söktes respondenter som enligt barnkonventionens definition var barn, dvs. som var under 18 år, vid tidpunkten för sammanbrottet. Två respondenter hade fyllt 18 år före intervjun. Fem av respondenterna bodde hemma eller $\mathrm{i}$ eget boende vid tidpunkten för intervjun, övriga befann sig i samhällsvård. För en beskrivning av respondenter och deras pla- ceringar se tabell 1 . Några barn hade svårt att minnas hur många placeringar de haft vilket betyder att antalet placeringar kan vara underskattat. I tabellen anges antalet tillfällen som barn bott i olika vårdmiljöer. Om barn placerats i samma vårdmiljö flera gånger räknas det som nya placeringar eftersom barnen beskrev det så. Inom parentes anges det totala antalet boendemiljöer inom en vårdkedja d.v.s. alla platser barn bott på från första placeringstillfället till tidpunkten för intervjun eller till barnens senaste placering. Även hemflyttningar räknas om dessa inte var stabila utan följdes av att barn återplacerades. Barnet i intervju 1 har t.ex. varit placerad 7 gånger i familjehem och HVB men har också flyttat hem 3 gånger däremellan så det totala antalet boendemiljöer under vårdtiden är 10 .

Urvalet har skett enligt "purposive sampling" vilket innebär att respondenter söktes som kunde förväntas ge riklig information om upplevelser av instabilitet (Smith m.fl. 2009). Ett nätverk av socialsekreterare från Västernorrlands län bistod i rekryteringen av barn. Dessa socialsekreterare tillfrågade barn som varit med om sammanbrott under åren 2011 eller 2012 när de var placerade av någon kommun i länet, om de ville delta i studien. Detta var en förutsättning för att få tillträde till barnen i och med att det inte finns något register över vilka barn som erfarit sammanbrott och p.g.a. att det krävs godkännande av flera "gatekeepers" innan frågan om deltagande kunde ställas till barnen. För att utesluta mycket kortvariga placeringar hade barnen varit placerade i minst två månader $\mathrm{i}$ vårdmiljön där sammanbrottet skedde. En förutsättning för deltagande 
var att barnen och deras vårdnadshavare samtyckte till medverkan. Socialarbetarna förmedlade informationsbrev om studien till barn, socialsekreterare, vårdnadshavare och i de fall barnen fortfarande var placerade, till vårdmiljön. För de två respondenter som fyllt 18 år inhämtades endast samtycke från dem själva. Undantag från vård- nadshavarnas samtycke gjordes för två barn som var över 15 år och hade en vårdnadshavare som inte gick att nå. Dessa barn ansågs kunna fatta egna beslut utifrån att 15 år tidigare bedömts vara en rimlig åldersgräns för ett självständigt ställningstagande om deltagande i forskning (Sallnäs m.fl. 2010). Det bedömdes dessutom vara mer oetiskt

\section{Tabell I.}

Intervjumaterialet. Kön, ålder, placeringar och placeringsorsaker.

\begin{tabular}{|c|c|c|c|c|c|}
\hline Kön & $\begin{array}{l}\text { Ålder vid } \\
\text { första } \\
\text { place- } \\
\text { ringen }\end{array}$ & $\begin{array}{l}\text { Ålder } \\
\text { vid } \\
\text { intervju }\end{array}$ & $\begin{array}{c}\text { Antal place- } \\
\text { ringar, inom } \\
\text { parentes } \\
\text { inklusive hem- } \\
\text { flytt }\end{array}$ & $\begin{array}{l}\text { Typ av place- } \\
\text { ringar }\end{array}$ & Orsak till placering \\
\hline Pojke & 9 & 15 & $7(10)$ & Familjehem, HVB. & $\begin{array}{l}\text { ADHD, eget beteende, } \\
\text { missbrukande föräldrar. }\end{array}$ \\
\hline Pojke & 7 & 12 & $2(2)$ & Familjehem. & $\begin{array}{l}\text { Missbrukande förälder, } \\
\text { omsorgssvikt. }\end{array}$ \\
\hline Flicka & 9 & 15 & $7(8)$ & $\begin{array}{l}\text { Familjehem, } \\
\text { släktingplacering. }\end{array}$ & $\begin{array}{l}\text { Missbrukande förälder, } \\
\text { omsorgssvikt. }\end{array}$ \\
\hline Flicka & 15 & 18 & I (I) & Släktingplacering. & $\begin{array}{l}\text { Missbrukande förälder, } \\
\text { omsorgssvikt. }\end{array}$ \\
\hline Flicka & 6 & 12 & $6(8)$ & Familjehem. & $\begin{array}{l}\text { Missbrukande förälder, } \\
\text { omsorgssvikt. }\end{array}$ \\
\hline Flicka & 14 & 18 & $5(6)$ & $\begin{array}{l}\text { Familjehem, HVB, } \\
\text { konsultstött } \\
\text { familjehem. }\end{array}$ & $\begin{array}{l}\text { Egna problem i form av } \\
\text { drogmissbruk, rymning } \\
\text { m.m. }\end{array}$ \\
\hline Pojke & 4 & 8 & $2(2)$ & Familjehem. & $\begin{array}{l}\text { Omsorgsbrist, utstöt- } \\
\text { ning. }\end{array}$ \\
\hline Pojke & 4 & 8 & $2(2)$ & Familjehem. & $\begin{array}{l}\text { Omsorgsbrist, utstöt- } \\
\text { ning. }\end{array}$ \\
\hline Flicka & 11 & 15 & $11(11)$ & $\begin{array}{l}\text { Familjehem, HVB, } \\
\text { SiS-institution. }\end{array}$ & Relationsproblem. \\
\hline Flicka & 13 & 15 & $8(8)$ & $\begin{array}{l}\text { Familjehem, HVB, } \\
\text { SiS-institution. }\end{array}$ & $\begin{array}{l}\text { Relationsproblem, eget } \\
\text { beteende. }\end{array}$ \\
\hline Pojke & 10 & 15 & $3(3)$ & Familjehem, HVB. & Missbrukande förälder. \\
\hline Pojke & 13 & 15 & $7(8)$ & $\begin{array}{l}\text { Familjehem, HVB, } \\
\text { SiS-institution. }\end{array}$ & $\begin{array}{l}\text { Eget missbruk och } \\
\text { kriminalitet. }\end{array}$ \\
\hline
\end{tabular}

${ }^{*}$ HVB (Hem för vård eller boende) är en institution som bedrivs yrkesmässigt i offentlig eller privat regi.

${ }^{* *}$ SiS-institution (särskilda ungdomshem hos Statens institutionsstyrelse) är en statlig institution med långtgående befogenheter att t.ex. isolera barn från andra boende på institutionen. 
att hindra barnen som ville delta från att medverka i studien än att frångå principen om vårdnadshavares samtycke.

\section{Intervjuprocedur}

Av sexton barn som kontaktades/tog kontakt var det tre som inte ville delta i studien eller var okontaktbara och ett barn som ville delta men som fick förhinder vid två tillfällen och därefter rymde från vårdmiljön. En intervjuguide med övergripande teman och frågor skapades. Syftet var att i förväg ringa in vad intervjuerna skulle omfatta och hur frågor optimalt kunde formuleras (Smith m.fl. 2009). Öppna frågor t.ex. "Berätta om din family" användes. Denna frågetyp valdes eftersom den möjliggör för barn att delge sina historier fritt samt ökar deras förutsättningar att ge detaljerad information (Cederborg m.fl. 2000).

Barnen valde att träffas $i$ vårdmiljön, hemma eller på restauranger. Innan intervjun påbörjades fick barnen återigen information om de forskningsetiska principerna. Intervjuerna varierade mellan ca 30 och drygt 60 minuter. Under intervjun styrde respondenternas berättelser intervjuns inriktning så länge deras berättelser var relevant för studiens frågeställningar. Intervjuguiden användes som en checklista för att säkerställa att relevant information var inhämtad.

\section{Dataanalys}

Alla intervjuer ljudinspelades och skrevs ut ordagrant. Vid transkriberingen har talspråk getts en skriftspråklig stavning. Utfyllnadsord samt dialektala eller ofullständiga ord har reducerats eller korrigerats. Analysen genomfördes i dataprogramet NVivo 9. Utifrån den tolkande fenomenologiska ansatsen söktes detaljer som visar på likheter och skillnader i barnens upplevelser av instabilitet (Smith m.fl. 2009). Varje intervju lästes i sin helhet och noteringar gjordes utifrån händelser, relationer, processer m.m. som bedömdes betydelsefulla för barnens upplevelser av instabilitet. När alla intervjuer analyserats jämfördes analyserna med varandra. Utifrån de mönster som framträdde grupperades noteringar i kategorier och övergripande teman.

Om citat kortats ned markeras detta genom tre punkter inom rundparentes. När något förtydligats eller intervjuarens fråga redovisas står det inom hakparentes. Utifrån att alla respondenter var barn när de erfor instabilitet $\mathrm{i}$ vården benämns respondenterna konsekvent som barn.

\section{Studiens begränsningar}

Denna studie eftersträvar att förstå och analysera barns perspektiv på instabilitet. När det gäller överförbarhet av resultat är det viktigt att ta hänsyn till studiens urval. Det finns en tyngdpunkt på barn med många placeringar och avsaknad av barn som endast erfarit planerade byten av vårdmiljöer. Flera barn hade också flyttat hem till den biologiska familjen och sedan återplacerats i samhällsvård. Respondenterna i studien gav dock, oav- 
sett kön eller ålder, liknande beskrivningar av sina upplevelser av instabilitetet. Detta tyder på att de erfarenheter barn i studien berättar om kan vara överförbara till andra barn som befinner sig $i$ liknade situationer.

\section{Vägen in i samhällsvård}

\section{Hög instabilitet kan göra det svårt att minnas och förstå sin placeringshistoria}

Att berätta sin placeringshistoria var svårt för barn som flyttat många gånger. I flera fall hade barn svårt att minnas när de placerades första gången och hur många placeringar de haft "Jag kommer inte ihåg ordningen riktigt". Vissa berättade att de dessutom flyttat med eller inom den biologiska familjen innan placeringen "Sen fick jag flytta hem till pappa för det fungerade inte hemma hos mamma". Flera barn berättade inledningsvis mycket kortfattat om byten av vårdmiljöer. Under intervjuns gång när de talade om sin placeringshistoria mindes de efterhand fler detaljer. Sättet att räkna antal placeringar verkar inte vara okomplicerat. Barns uppfattning kan skilja sig från socialtjänsten då t.ex. vissa korta perioder av boende hos biologiska föräldrar kan ha varit längre "permissioner" där placeringen rent formellt inte avslutats. Det är också troligt att institutionernas "straff" då barn som en konsekvens av ett dåligt beteende under en period flyttas till en annan institution, eller mellan olika avdelningar på institutionen, inte anges som en ny placering av socialtjänsten. Barnens berättelser om att flytta hem till biologiska föräldrar visar att detta i vissa fall kan jämföras med en ny placering då det kan innebära en "återanpassning" till den biologiska familjen.

"Jag hade bosatt mig hemma och börja komma in med familjen för alltså vi hade $j u$ trots all varit borta från varandra. Visst jag hade typ kommit hem emellanait men att komma hem lite då och då och att bo hemma det är helt skilda saker, det är andra regler och sådant."

Barnens beskrivningar av sin vårdhistoria tyder på att instabiliteten ur barnens perspektiv kanske är långt mer omfattande än vad socialtjänstens barnavårdsakter vid en första anblick visar. Figur 1 är ett exempel på hur placeringskedjan ser ut för det barn som hade flest placeringar.

\section{Figur 1.}

Placeringskedja för barnet med flest placeringar.

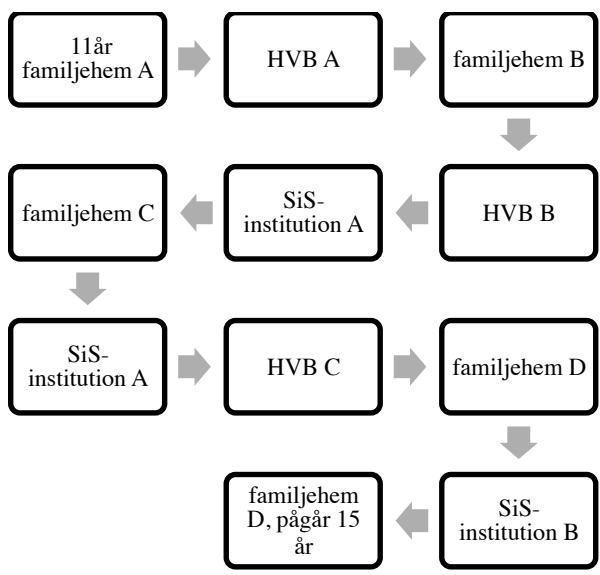




\section{Snabba placeringar och bristande information beskrivs leda till kaos}

Barnens uppfattning om orsakerna till deras placeringar finns sammanfattade $i$ tabell 1 och omfattar problem kopplade till deras beteenden och/eller föräldrarnas bristande förmåga. Några barn beskriver att de och socialtjänsten har olika syn på varför de behövde placeras. En flicka säger t.ex. att socialtjänsten inte tagit någon hänsyn till de svårigheter hon upplevt med att som tonåring invandra till Sverige. Denna diskrepans beskrivs få konsekvenser då hon inte tycker att placeringen hjälper henne och att hon ständigt försöker ta sig därifrån. Flera av barnen uppger att ingen tydligt har talat om orsaken till att de blev placerade.

"Alltså jag har ju aldrig riktigt fätt någon konkret riktig förklaring på varför jag blev placerad första gången. Men vad jag har hört det var att morsan inte ville att det skulle gå dåligt för mig (...) Jag var ju sjövild när jag var liten så jag misstänker att det kan vara lite sådant att hon inte riktigt orka med och kunde uppfylla mina behov."

Att barnen beskriver insikt om föräldrarnas problematik verkar inte per automatik innebära att de förstår varför de behövde placeras. Föräldrarnas problem beskrivs vara en del av barnens vardag.

"Jag var ju jättevan att mamma drack och höll på och festa med sina kompisar och sådär så det där var inget ovanligt. Men sen liksom, vad var det som hände nu då? Då sa de det är ju vanligt att mamma dricker och vi bara åkte iväg."

Som tidigare forskning visat upplever flera barn att deras placeringar sker plötsligt (Rostill-Brookes m.fl. 2011) "Det bara gick så fort (...) Vi satt oss $i$ socialtjänstens bil och vi hann inte säga hejdå eller något, vi bara åkte". Barnen kan ha svårt att förstå skälet till att placeringen gick så snabbt och några berättar att de försökte protestera "Han [polisen] släpade mig ifrån mamma, jag var 10 år. (...) Det var ju inte roligt tyckte jag. Jag skrek bara efter mamma". Barnens upplevelser av bristfällig eller i vissa fall utebliven information innebar att några barn inte ens vid placeringstillfället uppfattat att de skulle placeras "När man kom dit med morsan och så soctanten då liksom, nio bast och tänkte ja men morsan ska väl vara här också. Nej så vart man lämnad, då skulle de åka iväg. En fett tung känsla". I vissa fall uttryckte barn att de blev lurade att komma till socialkontoret för att sedan bli placerade. Ett barn skiljer sig från de andra i sin berättelse då hon själv initierade placeringen och beskriver en högre delaktighet "Då bestämde jag mig en dag för att berätta för Anna [socialsekreteraren] och fråga om hon kunde hjälpa mig (...) då gjorde vi upp en plan".

Bristande information och snabba placeringsprocesser kan, utifrån barnens berättelser, tolkas som orsaken till att situationen upplevs kaotisk och som början på vägen mot instabilitet. 


\section{Bristande matchning upplevs öka risken för instabilitet}

Om placeringar sker plötsligt kan det antas påverka möjligheten att matcha barn till rätt vårdmiljö. Detta får enligt barnen väsentlig betydelse för att vården sedan avbryts. Barnen beskriver bristande matchning i form av att de inte passar ihop med vårdgivare, att de placeras i en typ av vårdmiljö de inte vill vara i och att familjehemsföräldrar/personal har svårt att hantera deras problematik. Vissa barn skildrar hela sin vårdkedja som präglad av snabba placeringar och bristande matchning. Ett snabbt avslut av en placering beskrivs kräva en ny snabb lösning "Det är väl typ fem eller något [placeringar]. Enda gången som har varit planerad var när jag flyttade från HVB till första familjehemmet annars har det bara varit såhär direkt". Få barn uttrycker att de fått ta ställning till om de vill placeras i den aktuella vårdmiljön. Även barn som medverkat i beslutet säger att de behöver mer tid i vårdmiljön innan beslutet fattas.

"När jag varit där någon helg då fär jag säja om jag vill bo där eller inte och sen fär jag flytta dig några veckor senare eller någonting. Det fungerar väl bra men jag tycker man borde fä mer tid där, att det inte bara är någon helg sen måste man bestämma sig. För man vet inte hur de är efter bara en helg. Så har det ofta varit att när man har träffat familjen då har de varit snäll för då har soc varit med och sen har man varit där någon helg då är de jättesnälla och sen när man väl har flyttat dit då är de helt annorlunda."

Flera barn berättar att de hade en önskan om val av vårdmiljö men att de inte fått gehör för den "Alltså jag sa ju att jag ville hellre flytta till ett familjehem för det kändes som att det skulle fungera bättre att bo $i$ en familj där det är lite normalare än på behandlingshem". Barnen beskriver att deras initiala motstånd mot vårdmiljöer ofta bekräftas. En flicka som önskade en familjär miljö beskriver svårigheter med institutionslivet "Jag trivdes inte där. Jag gillade inte att de bytte personal hela tiden. Jag gillar inte att det skulle komma in nya tjejer, nytt folk hela tiden". Nästan alla barn uttrycker en tydlig önskan om en mer individuell bedömning för att hitta en lämplig placeringsform och att socialsekreterarna ska lyssna på vad barnen själva önskar "Lyssna på vad barnet vill och inte bara tänka på vad de tror kommer att bli bra, för att de kan ju inte veta vad barnet känner".

Sammanfattningsvis går det att konstatera att barn som inte upplever sig bli lyssnade till vid val av vårdmiljö riskerar att känna att de inte trivs i sin placering. När matchningen däremot fungerar beskriver barnen att det leder till att de mår bättre "Nu när jag har kommit till ganska bra ställen då går ju allt mycket bättre så nu har jag vart drogfri ganska länge och det beror ju påom man trivs".

\section{Vägen ut ur samhällsvård}

\section{Straff och missförhållanden kan ligga till grund för att barnen inte trivs}

Barn placerade på institution och i familjehem skiljer sig åt när det gäller hur de pratar 
om syftet med att de är placerade. Som Cederborg och Karlsson (2001) beskrivit uttrycker tonåringar, och i detta fall tonåringar med erfarenhet från institutionsvård, i hög grad placeringar som ett straff. Synen på placeringar som straff verka skapa en önskan hos barn att ta sig därifrån och rädsla för att återplaceras får en preventiv effekt när barnen flyttar hem.

Livet på institution beskrivs styrt av belöningssystem som reglerar barnens grad av frihet utifrån att "gott" beteende belönas och "dåligt" beteende bestraffas. Flera barn beskriver en rigid tillvaro där det gäller att ha "rätt" beteende gentemot de vuxna för att inte straffas.

"Sa man någonting fel till personalen på avdelningen framför någon annan så var det nu ska du fan få se att du sa det där. Det är ungefär nu ska du ångra dig att $d u$ sa det där (...) Var man liksom sådär lugn och gullig och liksom lyssna på dem även om de tryckte ner en och sådana saker då var man en bra person, men om man sa till dem när de gjorde fel då var man en dålig person."

I gränslandet mellan regler och missförhållanden finns kroppsvisitering och isolering, som SiS-institutioner har laglig möjlighet att använda $\mathrm{i}$ vården. En flicka beskriver hur hon skulle medverka i kroppsvisitering i samband med placeringens start "Det var typ fängelse, barnfängelse. När jag kom in sa de att jag skulle ta av mig kläderna och allting för de ska visitera och sådana saker och jag vägrade göra det. De fick trycka ner mig och tvinga mig göra det". Tiden på institutionen kom sedan i hennes ögon att handla om att hon protesterade mot tillvaron och ständigt blev bestraffad av personalen. Barnens upplevelser av isolering beskrivs som övergrepp där regler inte följs och barnens relation till personalen skadas.

"Det var en larmknapp där så om man tryckte på den då skulle de komma dit, det var ju en lag på det. Men de stängde av den så de hörde mig inte. Då bankade jag på dörren för att de skulle höra mig, så bara nej du bankade på dörren så du är inte lugn än. Så det har ingen effekt man blir bara surare."

Flera barn beskriver missförhållanden i form av fysisk och psykisk misshandel både i familjehemsvård och institutionsvård. För vissa barn, som inte uppfattade att de fick hjälp trots att de berättade om missförhållanden, ledde det till att de försökte ta sig därifrån. Den psykiska misshandeln beskrivs omfatta hot "Så hotade han mig och höll på i telefon", att barn bevittnar våld mellan familjehemsföräldrarna "När han drack då blev han aggressiv både mot sin fru och mot mig", att barn särbehandlas "De satt ner $i$ soffan och myste (...) medan vi satt uppe och hade typ svinträkigt" samt att barn skuldbeläggs "Det är ditt fel att du sitter här. Det är ditt fel, du betedde dig illa". Barnens beskrivningar av fysiskt våld varierar från slag till annat våld t.ex. att bli nypt. Missförhållanden beskrivs också i form av att barn får ta hand om syskon när familjehemsföräldrarna är berusade. Barn som kommer från en biologisk familj med missbruk uttrycker tydligt att det är jobbigt när familjehemsföräldrar dricker vilket leder till att de inte vill stanna i placeringen. 
"Jag tyckte det var jättejobbigt när han drack för då blev man påmind liksom om hur det var innan. Det tycker jag inte att man borde bli utan det är då man ska försöka få en chans till ett bättre liv och då känner man liksom bara ja att det går inte, att man vill inte bo där då."

En annan form av försummelse eller brister $i$ omsorgen är att barn uppger att de inte ges tillgång till att gå i grundskola eller gymnasiet med hänvisning till att de behöver anpassa sig till vårdmiljön först. Inte så förvånande beskriver barn hur upplevelser av missförhållanden påverkar dem i vardagen även efter placeringarnas avslut.

"Alltså det sätter ju sina spår på ett sätt men man kommer nog över det tror jag, åtminstone efter ett tag. Det här med hoten hur han kunde säga att jag var en dålig person och sådant det sätter spår. Man vill inte höra hur dålig man är liksom."

Barnen försöker hitta strategier att handskas med sina negativa upplevelser.

"Jag försöker ju hitta någon strategi för mig själv att jag ska kunna klara av dagarna. För så fort jag tänker på sådana ställen mår jag illa men jag menar man måste ju klara av att kunna leva med det också. Det har ju redan hänt och jag kan ju inte göra något àt saken nu."

Sammanfattningsvis beskriver barnen att rigid samhällsvård och missförhållanden kan ses som orsaker till att de inte trivs i sin placering och i förlängningen vara ett skäl till att vården bryter samman.

\section{Bristande inflytande beskrivs leda till olika strategier för att takontroll}

Vilket lagrum barnen är placerade enligt verkar inte ha någon betydelse för hur tvingande de upplever vården. Även barn som är frivilligt placerade beskriver sig som rättslösa och utan inflytande. När barn inte trivs i sin placering ger de exempel på att de försökt påtala det för omgivningen.

"Jag sa till soc att jag ville ha möte, så kom de väl dit. Då sa jag väl samma sak, att jag inte trivdes att det inte fungerade men det var typ som att de inte lyssnade. De tyckte väl bara att, äh jag vet inte. De trodde väl att det var bäst för mig men jag tyckte inte det. Jag mådde mest dåligt när jag bodde där."

Även när barnen berättar om konkreta missförhållanden finns exempel på att de inte tycker att vuxna tror på dem. I detta exempel berättar en pojke att familjehemsmamman slagit honom "Jag sa det till Sofia [socialsekreteraren] men hon trodde inte på mig hon bara sa nej. Så sa familjehemsmamman att hon klappade mig på kinden. Fan vad arg jag vart då. Det var det som gjorde så jag inte kunde vara där". Undantag finns där barn beskriver att socialtjänsten omedelbart agerar när de berättar om missförhållanden. Några berättar att de, som bevis för socialtjänsten, ljudinspelat missförhållanden som skett $i$ vårdmiljön "Jag spelade in deras röst hur de behandlade mig där (...) då förstod de att det var fel men innan det när jag inte hade några bevis lyssnade de inte på mig. Mina ord var tomma för dem". Barnens uppfattning av bristande 
förståelse från socialtjänsten beskrivs skapa frustration hos dem "Jag kan ju bli liksom sur och arg när någon inte lyssnar, ignorerar mig (...) då kunde jag skrika vad fan håller ni på med för jag visste inte hur jag skulle liksom hantera eller säga, hur jag skulle förklara för att visa mina känslor".

När barnens ord inte leder till förändring beskrivs två mönster av agerande. Antingen kapitulerar barnen och misstrivs men finner sig i situationen "Jag har ändå ett ganska vanligt liv nu så det gör inget om jag inte trivs så jättebra (...) Det är ingen idé att kämpa emot heller, man kan ju inte göra någonting förrän de är nöjd". Eller i annat fall agerar de genom att t.ex. gör sig själv illa, bli aggressiv eller rymma "Jag mådde sämre och sämre och allså jag började skära mig då ett tag för soc vägrade lyssna. Sen när polisen sa till då börja de lyssna. Så jag blev så sur för att det känns som att det var det enda sättet att få soc att lyssna att åka fast eller någonting". Det senare, att barnen agerar ut, beskrivs som den vanligaste strategin. Barnen berättar att de rymmer för att de inte trivs i placeringen $i$ kombination med att de upplever att ingen lyssnar när de påtalar detta "Jag rymde ju för att jag inte ville vara där. För att jag mådde så jävla dåligt där så då hade de väl kunnat lyssna mer och kanske gjort något åt det". När barnen rymmer innebär det, utifrån barnens berättelser, att de riskerar att vistas i olämpliga miljöer där det förekommer missbruk och kriminalitet.

Sammanfattningsvis skildras normbrytande beteende av barnen som ett sätt att få sin åsikt beaktad när ord inte räcker till. Vissa barn uttrycker att de lärt sig att utåtagerande beteende är det enda som får vuxna att agera och det enda sättet för dem att få slut på en placering de vantrivs i "Jag skrattade lite grann för mig själv och sa varför har jag inte gjort det här tidigare?".

\section{Placeringarnas avslut}

Sammantaget beskriver de 12 barnen 54 avslut av placeringar.

Tre barn beskrev att en av deras placeringar avslutats p.g.a. det inte längre fanns

\section{Figur 2.}

Avslut av placeringar, skäl som angavs av barnen.

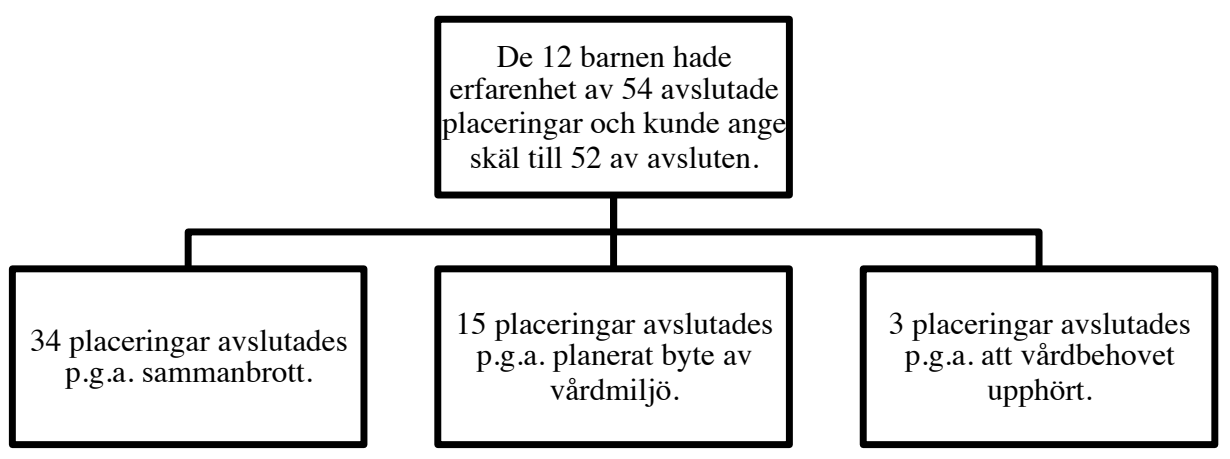


något vårdbehov. I alla dessa fall berättar barnen att de sedan återplacerades i samhällsvård. Barnen beskriver att samma problematik som föranledde den första placeringen också var orsak till att de återplacerades. För de fem barn som hade flyttat hem eller till eget boende vid tidpunkten för intervjun beskrevs skälet till samhällsvårdens upphörande vara sammanbrott. Barnens beskrivningar av brist på stabila hemgångar vid planerade avslut och bestående hemgångar trots att vården avbryts oplanerat kan tolkas som att socialtjänstens planering av barnens vård inte fungerar.

Barnen beskriver planerade byten av vårdmiljöer $\mathrm{i}$ form av att de flyttar från en jourplacering till mer långsiktig lösning eller att vården trappades ner till en friare vårdmiljö. Barnen kopplade svårigheten med att lämna en vårdgivare till hur väl de trivdes där och inte till huruvida flytten var planerad eller inte. Barnen beskrev utifrån detta planerade avslut från vårdgivare de trivs hos som svåra "Där trivdes jag jättemycket så man blev lite ledsen när man flyttade därifrån för där var det enda stället jag riktigt trivdes pä". Sammanbrott där barnen inte kom överrens med sina vårdgivare kunde däremot, trots att det var en svår upplevelse, beskrivas som en lättnad "Jag blev jätteglad när jag fick flytta".

\section{Bristande matchning, missförhaillanden och beteendeproblem upplevs orsaka sammanbrott}

Sammanbrott beskrivs som den vanli- gaste orsaken till att vården upphör. Enligt barnen orsakas sammanbrott av: bristande matchning mellan barn och vårdgivare, missförhållanden i vårdmiljön eller att barn blir utkastade p.g.a. beteendeproblem. Barnen bedömer att vissa avslut hade kunnat förhindras, men de flesta benämns som oundvikliga. Två av barnen i studien upplevde sammanbrott från släktingplaceringar. Sammanbrotten för dessa barn gav helt andra konsekvenser. Barnen förlorade inte bara kontakten med sin vårdmiljö utan bröt också all kontakt med sina släktingar. Ett av barnen återtog kontakten men beskriver att den aldrig kan bli densamma.

Beteendeproblem beskrivs vanligtvis kopplat till missförhållanden i placeringen eller till svårigheter att hantera känslan av att vara placerad "Jag var arg hela tiden, till slut fick inte jag bo där för att jag bråkade och sådant (...) [Varför var du arg?] För att jag saknade min familj". För barn som placerades på grund av beteendeproblem beskrivs i vissa fall en paradoxal situation då de problem som ledde till att barnen hamnade i samhällsvård även blev orsaken till att vården avslutades (jfr Egelund m.fl. 2010). Det finns även barn som beskriver att de utvecklar beteendeproblem under placeringen. Detta har i forskning benämnts som "smittoeffekter" eftersom barn utvecklat beteendeproblem i interaktion med andra placerade barn (ibid.). Flera barn i denna studie menar dock att de börjar ta droger, får självskadebeteenden eller begår kriminella handlingar utifrån att de inte trivs i placeringen "Jag skar mig och sådant bara för att man mår så psykiskt dåligt så vet man inte vad man gör". Även de barn som beskriver 
beteendeproblem som en effekt av att de inte trivs med institutionsstrukturen illustrerar en paradoxal situation. Barn berättar att de agerar ut när de har svårt att hantera en rigid vårdmiljö men riskerar då att placeras i en än mer strukturerad vårdmiljö. En flicka berättar t.ex. att hon hade svårt att hantera saknaden av familjen "Jag fick inte gå ut, jag saknade min familj och mina kompisar och det var såhär låst (...) jag bara blev arg hela tiden och bråkade jättemycket för jag klarade bara inte av det där (...) jag kände mig såhär ensam". Hennes agerande ledde visserligen till att placeringen avslutades men flickan blev istället som 1 låring placerad på en SiS-institution. Flera barn berättar om denna "upptrappningsstruktur".

Den genomgående röda tråden i barnens berättelser om olika utåtagerande beteenden är att barnen agerar utifrån hur de uppfattar sin situation. Den mest primära önskan är att bli lyssnad till och få bo hos någon de trivs hos "De kunde väl ha lyssnat $i$ alla fall. Alltså det hjälper inte att sätta mig på ett ställe bara och tro, tvinga en att det ska fungera om det inte gör det liksom. Då är det ju ingen ide att jag bor där". Sammanbrott som straff beskrivs både i familjehem och på institution. Barnen säger att det används som en konsekvens för ett icke önskat beteende. Barnen får under en tid flytta till en ny vårdmiljö för att sedan flytta tillbaka "Om man missköter sig $p a ̊$ ett behandlingshem då kan man få en konsekvens på två eller tre veckor bara för att byta miljö". Flera barn uttrycker, trots vissa synpunkter på skälen till dessa "konsekvenser", att det är en bra lärdom för dem om de gör fel.
Oavsett om instabilitet beror på en planerad flytt eller ett sammanbrott beskriver flera barn en tydlig brist på delaktighet när det gäller beslutet att flytta "Om bara jag hade velat flytta därifrån då hade jag inte fätt gjort det men om de säger att jag måste flytta därifrån då måste jag”. När andra fattar beslut om att vården ska upphöra beskriver barnen hur de "flyttas", att vårdgivarna "inte vill ha mig" eller inte "orkar med" och att de inte har så mycket att säga till om när besluten fattas. Några av barnen pekar också på behovet av att alltid få ett bra avslut.

"Alltså jag hade ju önskat att det vart som det första. Man blir hemkörd kanske tog en fika, prata och kramar och sen hejda liksom. (...) Jag hade önskat att det var ett bättre avslut liksom. Att det borde vara ett måste hur än situationen har varit för det är lättare att gå vidare om man får ett riktigt avslut."

De flesta barnen beskriver att instabilitet, oavsett om det är planerat eller inte påverkar dem länge efteråt. Vissa barn beskriver att det skapar en ständig oro över att behöva flytta igen.

"Man har ju blivit sviken så många gånger, behövt flytta, har aldrig hunnit bosätta sig, har aldrig hunnit känna det här är mitt hem innan man har flyttat igen (...) Det känns som att jag ska flytta igen. Alltså jag är beredd på det hela tiden, på beskedet att de inte kan ha kvar mig." 


\section{Sammanfattande diskussion}

Forskning visar att det är vanligt att barn erfar instabilitet i samhällsvård. Åtskilliga studier angående instabilitet har genomförts men få utgår från barnens perspektiv. Barnen i denna studie bekräftar till viss del tidigare forskning men beskriver sig själva på ett mer nyanserat sätt och som Egelund m.fl. (2010) uttrycker inte reducerat till stereotyper. Barnens berättelser delger inte någon oproblematisk sanning av vad som faktiskt skett utan beskriver hur de upplever och förstår instabilitet. Ett exempel är att barn som har föräldrar med missbruksproblematik beskriver att de upplever obehag när familjehemsföräldrar dricker alkohol. Detta leder i några fall till att barnen vill flytta. Barnens upplevelser säger inte något om huruvida familjehemsföräldrarna har ett missbruk. Däremot går barnens berättelser att tolka som att vuxna, i detta fall familjehemsföräldrar, behöver ta hänsyn till barnens tidigare erfarenheter av problem i hemmiljön.

Denna artikel visar på vikten av att studera såväl sammanbrott som planerade byten av vårdmiljöer. Barnen beskriver att svåra känslor i samband med att de flyttar är kopplat till hur väl de trivdes hos vårdgivaren och inte till om flytten är planerad eller inte. Att även planerade byten av vårdmiljöer upplevs svårt blir särskilt anmärkningsvärt då denna instabilitet kan ses som konstruerad i barnavårdssystemet. Socialtjänsten planerar i dessa fall för att barn ska flytta till en ny vårdmiljö oavsett om det är en flytt från ett jourhem till en mer långsiktig lösning eller en nedtrappning till en friare vårdmiljö.
Vägen mot instabilitet i form av sammanbrott börjar, utifrån barnens förståelse, redan vid placeringens start som ofta sker akut med bristande information och matchning som följd. När barn påtalar att de av olika skäl inte vill vara kvar i sin placering och de upplever att detta inte tas på allvar agerar de ut. Om vuxna inte lyssnar på barn men däremot handlar utifrån att barn har ett normbrytande beteende, riskerar barnen att lära sig att argumentation inte är ett framkomligt sätt att kommunicera. Likt Christiansen m.fl. (2010) beskrivit kan barnen då se normbrytande beteende som den enda utvägen för att få slut på en placering de inte trivs i. Om inte aktörer i barnens omgivning tagit del av barnens syn på varför de agerar ut, riskerar barnens reaktioner att reduceras till individuella problembeteenden. Denna studie tyder på att en placerings upphörande kanske inte kan eller ens bör undvikas om barn påtalar att de vill flytta. Även om barn beskriver sammanbrott som svårt kan det tolkas som slutet på en period där barnen vantrivts. Barn i denna studie hänför främst sammanbrott till strukturella faktorer inom socialtjänsten (bristande planering, information, matchning och kontroll av vårdmiljöer) samt brister hos vårdgivare (utifrån rigida strukturer och missförhållanden). När barnens eget agerande beskrivs som orsaken till sammanbrott uppger barnen att det finns skäl för dem att agera som de gör. Barnen hänför främst beteendeproblem till vårdgivares svårigheter att hantera deras problematik eller som svar på brister hos socialtjänsten och vårdmiljöer.

Barnens berättelser om instabilitet ges 
ur två olika perspektiv. I ena fallet agerar barnen aktivt för att få avsluta placeringar de inte trivs i. I det andra fallet är barnen oavsett vad de själva tycker inte längre välkomna $i$ vårdmiljön p.g.a. sina problem eller ett planerat byte av vårdmiljö. De barn som är i samhällsvård har många gånger upplevt svårigheter $\mathrm{i}$ hemmet. Att barn som placeras på grund av missförhållanden upplever sig bli ignorerade när de påtalar missförhållanden hos vårdgivare är oroväckande. Det är också bekymmersamt att barn som beskriver att de känner sig ensamma och har svårt att hantera institutionsmiljön, upplever sig bli straffade med en än mer sluten institutionsmiljö. Det har i tidigare kvantitativ forskning visats att många placeringar/tidigare sammanbrott är en riskfaktor för fortsatt instabil vård vilket även denna studie tyder på (jfr Oosterman m.fl. 2007; Strijker m.fl. 2008; Vinnerljung m.fl. 2001). Barnens berättelser kan tolkas som att det finns risk för att instabilitet reproduceras. Plötsliga avslut tenderar att generera nya snabba lösningar som inte blir bestående och leder till att barn vid upprepade tillfällen måste flytta. De barn som varit med om en mängd placeringar har svårt att överblicka och förstå sin placeringshistoria. Som tidigare forskning visat beskriver barnen mycket begränsade möjligheter till makt och inflytande över sina liv. Barnen beskriver att de befinner sig på en resa med okänt mål då de inte vet vad som ska hända härnäst eller hur länge de får bo kvar i sin vårdmiljö (jfr Rostill-Brookes m.fl. 2011). Det är rimligt att fundera över om inte de flesta barn som befinner sig i samhällsvård behöver samtalsstöd för att bearbeta sina erfarenheter och förstå vad som händer. Detta torde särskilt gälla för barn som upplevt instabilitet.

Det går inte att veta vad som hade hänt om andra beslut hade fattats vid vissa tidpunkter t.ex. beslut kopplade till processen vid omhändertagandet och val av vårdmiljö. Utifrån barnens berättelser går det dock inte att utesluta att smärtsamma upplevelser och brustna relationer hade gått att undvika om mer hänsyn tagits till barnens åsikter.

\section{Implikationer}

Denna studie indikerar att barn behöver involveras i matchningsprocessen samt att socialtjänsten bör undvika snabba placeringsförlopp och tillfälliga placeringar. Barn behöver få löpande information, som de kan ta till sig, om orsaken till att de placerats och om sin placeringshistoria. Om barn berättar att de inte vill stanna i en placering behöver detta tas på allvar. Utsikterna för att en placering ska gå att genomföra om barnen inte trivs verkar vara små. Barnens berättelser tyder dessutom på att de påverkas negativt om de tvingas stanna $i$ en placering de inte trivs i. När barn agerar med normbrytande beteende är det viktigt att försöka fånga barnens perspektiv. Detta minimerar risken att barn blir problembärare för brister hos vårdgivare och socialtjänst. Barns berättelser måste få en central betydelse både i forskning och praktiskt socialt arbetet. Först då kan förståelsen för samhällsvårdade barns situation öka och barnen kan erbjudas stöd som de själva upplever relevant. 
Ett stort och varmt tack vill jag rikta till de barn som tog sig tid att berätta om sina upplevelser av att bo i samhällsvård, tack för att ni lät mig ta del av er kunskap. Jag vill också tacka Allmänna barnhuset och FAS som finansierat studien samt de socialsekreterare som tagit sig tid att rekrytera barn till projektet.

\section{Referenser}

Cederborg, A.C. \& Karlsson, Y. (2001). Omhändertagande med barnets perspektiv. Socialvetenskaplig tidskrift, 3, s. 163-179.

Cederborg, A.C., Orbach, Y., Sternberg, K. \& Lamb, M. (2000). Investigative interviews of child witnesses in Sweden. Child Abuse and Neglect, 24(10), s. 1355-1361.

Chamberlain, P., Price, J., Reid, J., Landsverk, J., Fisher, P.A. \& Stoolmiller, M. (2006). Who disrupts from placement in foster and kinship care? Child Abuse and Neglect, 30(4), s. 409424.

Coy, M. (2009). Moved around like bags of rubbish nobody wants: How multiple placement moves can make young women vulnerable to sexual exploitation. Child Abuse Review, 18(49), s. 254-266.

Cristiansen, Ø., Havik, T. \& Anderssen, N. (2010). Arranging stability for children in long-term out-of-home care. Children and Youth Services Review, 32(7), s. 913-921.

Egelund, T. (2006). Sammenbrud i anbringelser en forskningsmoessig belysning. Socialforskningsinstituttet, Köpenhamn.

Egelund, T., Böcker-Jakobsen, T., Hammen, I., Olsson, M. \& Høst, A. (2010). Sammenbrud $i$ anbringelseraf unge. Socialforskningsinstituttet, Köpenhamn.

Hyde, J. \& Kammerer, N. (2009). Adolescents' perspective on placement moves and congregate settings: Complex and cumulative instabilities in out-of-home care. Children and Youth Services Review, 31(2), s. 265-273.

Khoo, E., Skoog, V. \& Dalin, R. (2012). In and out of care. A profile and analysis of children in the out-of-home care system in Sweden. Children and Youth Services Review, 34(5), s. 900-907.

Larkin, M., Watts, S. \& Clifton, E. (2006). Giving voice and making sense in interpretative phenomenological analysis. Qualitative Research in Psychology, 3(2), s.102-120.

Newton, R.R., Litrownik, A.J. \& Landsverk, J.A. (2000). Children and youth in foster care: Disentangling the relationship between problem behaviours and number of placements. Child Abuse and Neglect, 24(10), s. 13631374.

Oosterman, M., Schuengel, C., Wim Slot, N., Bullens, R. \& Doreleijers, T. (2007). Disruptions in foster care: A review and meta analysis. Children and Youth Services Review, 29(1), s. 53-76.

Rostill-Brookes, H., Larkin, M., Toms, A. \& Churchman, C. (2011). A shared experience of fragmentation: Making sense of foster placement breakdown. Clinical Child Psychology \& Psychiatry, 16(1), s. 103-127.

Sallnäs, M., Wiklund, S. \& Lagerlöf, H. (2010). Samhällsvårdade barn, gate-keeping och forskning. Socialvetenskaplig tidskrift, 17, s. 116133.

Skoog, V., Dahlin, R., Rönnbäck, E. \& Khoo, E. (2012). Instabilitet för barn i samhällsvård. Socionomens forskningssupplement, 31, s. 34-43.

Smith, J.A., Flowers, P. \& Larkin M. (2009). Interpretive Phenomenological Analysis. Sage, London.

Socialstyrelsen (2012). Barn och unga - insatser år 2011. Socialstyrelsen, Stockholm.

Strijker, J., Knorth, E.J. \& Knot-Dickscheit, J.

Viktoria Skoog: Barns upplevelser av instabil samhällsvård 
(2008). Placement history of foster children: A study of placement history and outcomes in long-term family foster care. Child Welfare, 87(5), s. 107-124.

Unrau, Y. (2007). Research on placement moves: Seeking the perspective of foster children. Children and Youth Services Review, 29(1), s. 122-137.

Unrau, Y., Seita, J. \& Putney, K. (2008). Former foster youth remember multiple placement moves: A journey of loss and hope. Children and Youth Services Review, 30(11), s. 12561266.
Vinnerljung, B. \& Sallnäs, M. (2008). Into adulthood: A follow-up study of 718 young people who were placed in out-of-home care during their teens. Child \& Family Social Work, 13(2), s. 144-155.

Vinnerljung, B., Sallnäs, M. \& Kyhle-Westermark, P. (2001). Sammanbrott vid tonårsplaceringar. Socialstyrelsen, Stockholm.

Ward, H. (2009). Patterns of instability: Moves within the care system, their reasons, context and consequences. Children and Youth Services Review, 31(10), s. 113-118.

\section{Summary}

\section{Children's experiences of unstable out-of-home care}

This paper describes children's experiences of instability in out-of-home care. Using an interpretive phenomenological methodology, twelve children were interviewed. The children gave similar descriptions of planned placement changes and placement breakdown. The difficulty with which these children experienced the move from a foster family or group home depended on their relationship to caregivers. Therefore, planned placement changes from foster homes or institutional settings in which children reported being happy were described as more difficult than break- down in placements from which children wanted to move. In the children's views, breakdown was caused by mismatches between them and caregivers, mistreatment in care settings, and their own behaviour problems. However, children explained that when social workers did not listen to them, behaviour problems in the form of running away, self-harming or behaving badly were the only way of ending placements in which they were miserable. Findings show that children's perspective is important and helps to create a holistic understanding of instability in care. 